\title{
THE QUALITY OF LIFE OF THE RESIDENTS OF TOURIST RECEPTION AREAS ACCORDING TO SELECTED INDICATORS
}

\author{
HANNA MICHNIEWICZ-ANKIERSZTAJN, ${ }^{1}$ IWONA JÓZEFOWICZ ${ }^{2}$
}

\author{
Uniwersytet Kazimierza Wielkiego w Bydgoszczy, POLAND \\ Instytut Geografii, Wydział Kultury Fizycznej, Zdrowia i Turystyki \\ ${ }^{1}$ e-mail: hanka@ukw.edu.pl \\ ${ }^{2}$ e-mail: jozefowicz@ukw.edu.pl
}

\section{KEYWORDS | tourist reception areas, macroeconomic indicators, tourism, quality of life}

ABSTRACT

\section{Introduction}

According to the World Tourism Organisation (2015 International Tourism Results and Prospects for 2016, UNWTO), tourism has become one of the fastest growing economic sectors in the world. The growing number of international tourist arrivals (which in 2015 exceeded 1.2 billion) results (on a global scale) in an increasing number of jobs, growing income from tourism 
and development of tourist facilities (connected with the growth of investment activity) (Besana, Bagnasco, 2014).

However, it must be emphasized that many researchers have still sought to answer the question whether it is tourism that promotes economic activity or whether economic activity leads to a growth in tourism (Antonakakis, Dragouni, Filis, 2015, p. 142). This is particularly noticeable in theoretical considerations resulting in the following hypotheses: tourism-led economic growth TLEG, economic-driver tourist growth - EDTG and bidirectional causality BC, no-causality NC (Chatziantoniou et al., 2013). Attempts at verifying the above-mentioned hypotheses by numerous researchers (including Dwyer et al., 2004) indicate that the relationships (and their magnitude and direction) existing between tourism and the economic development of a specific area are determined by multiple factors and change with time (Antonakakis, Dragouni, Filis, 2015).

Without doubt, in some countries tourism can determine the economic growth, which is manifested in the high share of tourism in the specific country's GDP (Gross Domestic Product). In countries where the economy is strongly dependent on tourism (countries at the medium stage of tourist monoculture, countries dependent on revenues from tourism), the contribution tourism makes to the GDP exceeds 30\% (Jasiński, 2008). These are mostly post-colonial countries which became independent in the second half of the $20^{\text {th }}$ century and changed their economic profile by transforming it into a tourism-based economy thanks to a favourable geographical situation, and climatic and natural values (Jasiński, 2008). Most of them, as a result of "tourist colonization" (Jędrusik, 2003) turned into tourist reception areas based on the $3 \mathrm{~S}$ (sun, sea, sand).

GDP is a key macroeconomic indicator of the wealth of a particular country. However, in many cases this is not directly reflected in the financial situation of its residents, nor in the level of social development and well-being of the people (Besana, Bagnasco, 2014; Beslerova, Dzuričkova, 2014). Studies carried out in developing countries, where the tourist market is a large source of income, estimate that $55-75 \%$ of expenditure on tourism in the reception countries returns to developed countries in the form of import expenditure or income of businesses and foreign workers (Blake, Arbache, Sinclair, Teles 2007, after McCulloch, Winters, Cirera 2001, p. 248; Jędrusik, 2003), describing the models of tourist colonization, has indicated that in two out of three types of colonization, foreign investors in the tourism industry of the specific country siphon the earnings outside and make no contribution to the local economy. This happens in the isolation model (where tourism business is completely isolated from the local community) and the parasitic model (where external investors constitute serious and efficient competitors for the local community involved in tourism business on a small scale).

Thus, one should consider to what extent the population of those countries whose economies are largely tourism based (reflected by the high share of tourism in the GDP and high percentage of employees working in tourism) makes use of earnings from this branch of economy. Also, it seems important to ascertain to what extent the high level of employment in tourism (residents' income from work in tourism and related industries) is reflected in the actual spending of households on goods and services. It could also be considered whether income from tourism in countries specialising in tourism is allocated to the development of the national labour market, and social 
and technical infrastructure, measured by access to education, the labour market and health care. In other words, it should be considered whether countries with a high contribution of tourism to the GDP are characterised by an increase in the quality of life of their residents measured according to the human development index (HDI). Here, it should be emphasized that the term "quality of life" is investigated at many levels by researchers from various fields and countries, which is recounted by Trzebiatowski 2011 and Haron, Osman et al., 2015. Therefore, a definition presented by the World Health Organisation (Beslerova, Dzurickova, 2014 after ISOQL, 2008) was adopted for the purposes of the study. It makes reference to "a life which reflects how people perceive their place of life, in culture and value system where they live and where they make a relationship to objectives, standards or interests".

\section{Resullts}

This study aims to capture the relationship between the economic development of tourismbased countries and the quality of life of their inhabitants.

In order to correctly identify whether and to what extent the aforementioned relations exist the k-means clustering approach was applied, dividing countries into three groups. The first group consisted of countries characterised by a high number of tourist arrivals with a low contribution of tourism to the GDP and low level of employment in tourism. The second group comprised countries with a low ratio of tourist reception and a high contribution of tourism to the GDP and a high level of employment in tourism. The third group was formed by countries with a low ratio of tourist reception, low contribution of tourism to the GDP and a low level of employment in the tourism industry. As a result of statistical analysis, the second group - of interest to the present authors involved 12 countries and dependent territories: Antigua and Barbuda, the Bahamas, Barbados, Belize, Cape Verde, Dominica, Fiji, Macao SAR, China, Maldives, Seychelles, St. Lucia, and Vanuatu. All the above-mentioned countries are characterised by a very large contribution of tourism and leisure to the GDP (from $32 \%$ to nearly $90 \%$ ).

A relationship between the development of tourism (which plays a significant role in the economy) and the financial situation and the quality of life of residents of the above-mentioned countries was propounded. To this end, indicators referring to the tourism industry such as: the contribution of tourism to creating the GDP, the percentage of employees working in tourism and the number of tourist arrivals to the specific country were looked at. The quality of life of the residents was examined using a synthetic index - HDI, which is defined as the geometric average of three dimensions - longevity, education and standards of living (Blancard, Hoarau, 2013, p. 624), as well as the GDP per capita and the level of spending on goods and services by households.

In order to capture the existing relations a dynamic analysis was performed. Thus, statistical data refers to the period 2000-2013. In order to verify the research assumption mathematical and statistical methods were used - among other things, the dynamics of change was calculated, the above-mentioned k-means approach was applied and selected indicators were correlated. The relationship between variables was also estimated using regression analysis. 
Countries subject to detailed analysis are island locations (except Macau - a dependency of China, and Belize in Middle America). Maldives, Fiji, Cape Verde, and Seychelles are independent countries. Belize, St. Lucia, Dominica, Antigua and Barbuda, Barbados, and the Bahamas, despite having regained their independence in the 1970s, are still a part of the Commonwealth and are to some extent dependent on the Monarchy of the United Kingdom. On the other hand, Macau is a special administrative region of China, with a separate legal, administrative, economic and monetary system. ${ }^{1}$ The above-mentioned island countries are members of the organisation of Small Island Developing States. In terms of economy, the associated states are characterised by a high dependency of the economy on import and high volatility of economic growth, limited opportunities for the private sector and a proportionately large reliance of their economies on their public sector (UN-OHRLLS, 2011, Small Islands Developing States, p. 2). Taking into account the values of the Tourist Penetration Index (based on receipts from tourism measured per capita), at the beginning of the $21^{\text {st }}$ century, Fiji, Vanuatu and Cape Verde were among the least tourism-developed countries (i.e. "the low end or beginning stage of the resort cycle", McElroy, 2003, p. 237).

Other island states were in the group of intermediate tourism-developed countries "characterized by very rapid visitor growth and hotel and infrastructure construction" (McElroy, 2003, p. 238).

In order to answer the questions posed at the beginning of this paper, a number of useful indicators referring both to the economic situation of the countries and the financial situation and the quality of life of their residents were analysed. These include: Travel \& Tourism Total Contribution to GDP, GDP per capita (at fixed 2005 prices - US Dollars), Household Consumption Expenditure (GDP by Expenditure, at fixed 2005 prices - US Dollars), Total Contribution of Tourism to Employment, and Human Development Index.

The dynamic analysis of the indices (between 2000-2015) made it possible to determine certain differences as illustrated in Table 1. In two countries (Fiji and Seychelles) the growth dynamics can be observed for all the selected indicators. In the first of them, a large increase in the number of tourist arrivals was observed along with a growing share of tourism and leisure in the GDP and employment in tourism as well as increasing household expenditure. Also, the GDP per capita is growing. In the case of the Seychelles, a large increase in the number of arrivals was associated with an average increase of the remaining indicators (about 30\%). In both cases the positive dynamics of changes in HDI is insignificant (1.39\%).

Taking into account the number of tourist arrivals in 2000-2013, out of the analysed countries only two were characterised by negative dynamics (the Bahamas and Barbados). In other countries the growth ranged from several percent to more than $330 \%$ for Cape Verde. The highest increase in employment in the tourism sector in 2000-2015 was recorded in Cape Verde (ca. 150\%). In five countries a decreasing level of employment in this sector of the economy was observed - from 5 to more than $26 \%$.

\footnotetext{
${ }^{1}$ Here, it should be emphasized that the authors had difficulties finding reliable data concerning indicators necessary for the purposes of analysis in this region. Therefore, they decided not to take it into account in further analyses.
} 
Considering the financial situation of the residents of the analysed countries it can be concluded that in nearly all cases an increase in household expenditure was observed: the highest in Dominica (137\%) and Fiji (98\%). In the investigated period the dynamics decreased insignificantly in the Maldives $(-0.4 \%)$ and in Cape Verde $(10 \%)$ only. In the period under discussion, the GDP per capita increased in 10 countries, and only in the Bahamas was a 13 per cent decrease in this ratio recorded. The last selected indicator connected with the quality of life of residents is the synthetic HDI. Among the selected countries, only in one case - Vanuatu - was a decreasing trend observed in this indicator. Other countries either maintained a stable position (Belize, Dominica) or recorded small increases (by a maximum of $5.33 \%$ in the case of Barbados).

Table 1. Dynamics of changes in selected indicators in 2000-2015

\begin{tabular}{|c|c|c|c|c|c|}
\hline $\begin{array}{c}\text { Number } \\
\text { of arrivals } \\
2013 \\
(2000=100)\end{array}$ & $\begin{array}{l}\text { Travel \& Tourism } \\
\text { Total Contribution } \\
\text { to GDP } 2015 \\
\quad(2000=100)\end{array}$ & $\begin{array}{c}\text { Total } \\
\text { Contribution } \\
\text { to Employment } \\
2015 \\
(2000=100)\end{array}$ & $\begin{array}{l}\text { Household consumption } \\
\text { expenditure (constant } \\
2005 \text { prices - US\$) } \\
2013 \\
(2000=100)\end{array}$ & $\begin{array}{c}\text { GDP } \\
\text { per capita, } \\
\text { constant } 2005 \\
\text { prices - US\$) } \\
2014 \\
(2000=100)\end{array}$ & $\begin{array}{c}\text { HDI } \\
2014 \\
(2000=100)\end{array}$ \\
\hline 17.9 & 2.2 & -18.1 & 58.1 & 9.0 & 0 \\
\hline-11.7 & 22.2 & -5.3 & 27.7 & -13.3 & 2.6 \\
\hline-6.6 & 4.6 & 0.6 & 39.4 & 6.1 & 5.33 \\
\hline 50.0 & 66.2 & 69.2 & 47.8 & 15.4 & 0 \\
\hline 337.4 & 149.7 & 153.5 & -10.8 & 63.5 & 4.84 \\
\hline 11.4 & 43.9 & 42.4 & 137.7 & 27.1 & 0 \\
\hline 123.8 & 49.6 & 49.8 & 98.4 & 18.6 & 1.39 \\
\hline 174.5 & 58.3 & 103.0 & no data & 232.6 & no data \\
\hline 140.9 & -28.9 & -26.6 & -0.4 & 13.7 & 2.9 \\
\hline 76.9 & 26.9 & 29.4 & 34.5 & 36.4 & 1.32 \\
\hline 18.1 & -10.9 & -6.7 & no data & 2.2 & no data \\
\hline 89.7 & -15.7 & -15.6 & 31.8 & 2.4 & -4.84 \\
\hline
\end{tabular}

Source: own elaboration based on www.knoema.org (15.01.2016).

The authors correlated the selected indicators in their search for relationships between economic development based on tourism and the quality of life of the residents. The analysis of correlations is characterised by variability in different periods of the study. Initially (2000) the correlation between multiple characteristics was significant. The strongest relationship occurs between the number of arrivals and the number of employees in the tourism and leisure industry (0.93) and the contribution of the tourism and leisure industry to the GDP and the level of employment in tourism (0.91). The number of arrivals and the GDP per capita (0.86), household expenditure and the GDP per capita (0.77) were also highly correlated, whereas a high negative ratio was recorded for the relationship between HDI and employment in tourism $(-0.73)$.

The number of relations characterised by a high and very high level of correlation decreased at subsequent time intervals. For 2010 there was a significant relationship between characteristics such as: employment in tourism and contribution to the GDP (0.93), and the number of arrivals and 
household expenditure (0.86). The least significant relationships between the characteristics were observed in the last period of the study. Only the number of tourist arrivals and household expenditure (0.72) were highly correlated. Since GDP per capita is a part of the synthetic HDI, the authors decided not to take the result of the correlation of the two characteristics into account.

As a result of the multiple regression analysis in the studied group of countries certain relationships were discovered between independent/predictor variables referring mainly to the condition and structure of the economy and dependent/criterion variables represented by the quality of life of the residents measured by HDI and the level of household expenditure. A positive correlation was found to exist between the number of tourist arrivals and household expenditure throughout the analysed period (Figure 1).
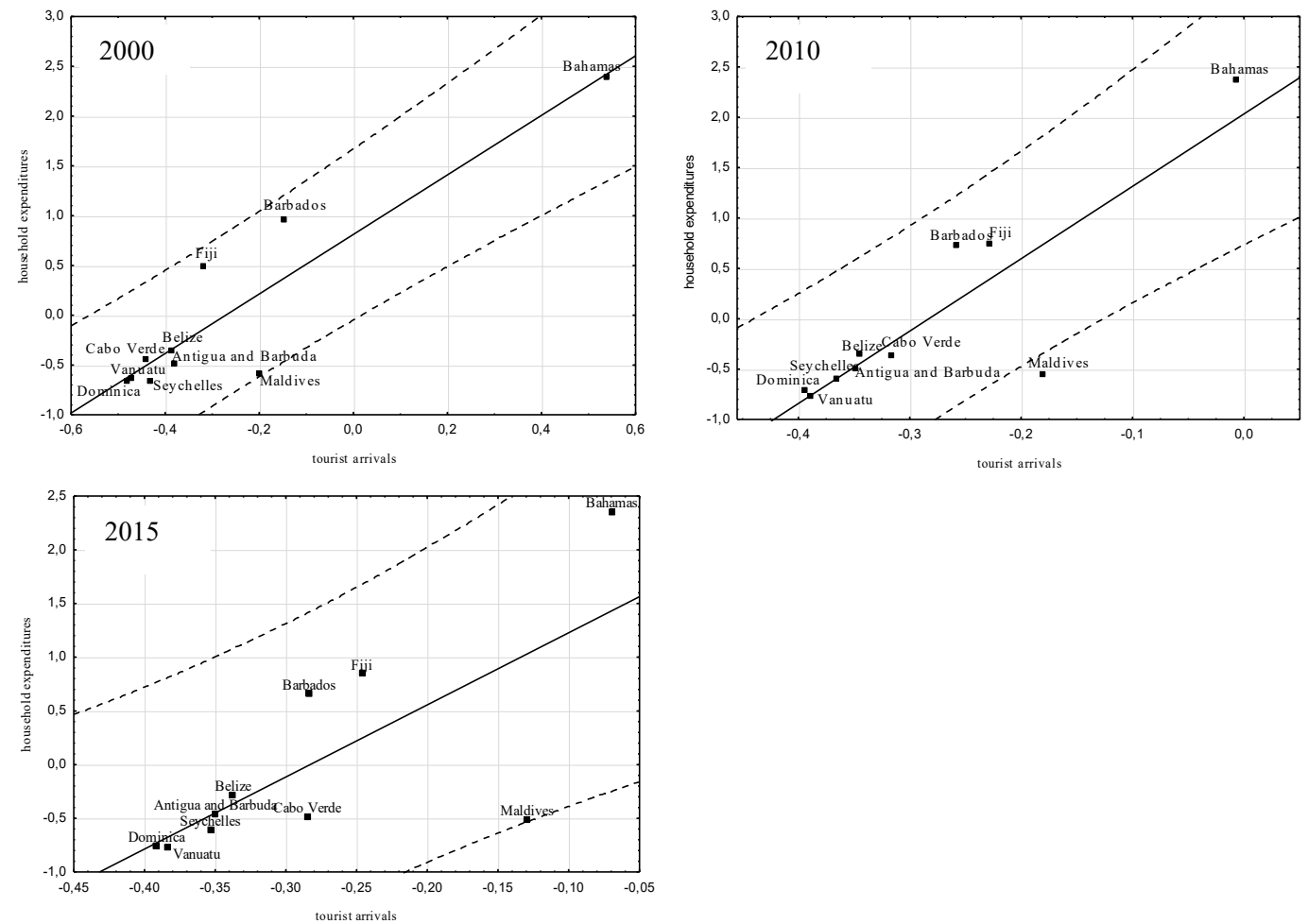

Figure 1. Scatter plots illustrating the relationships between the number of tourist arrivals, household expenditure in countries with a high contribution of tourism to the GDP in 2000-2015

Source: own elaboration.

The continuing increase recorded in the number of tourists arriving to the analysed countries and consequent spending in the reception countries contributed to improving the financial situation of the population (which is reflected by the growth in GDP per capita throughout the analysed 
period). Thus, compared to 2000, both in 2010 and in 2014 the options of spending household income on purchasing goods and services increased. This is most visible in the case of three countries - the Bahamas, Barbados and Fiji.

However, the development of the tourism industry in the studied countries did not directly translate into a rapid increase in the quality of life of their residents in 2000-2015. At the beginning of the analysed period (2000) this relationship was negative. The increase in employment in tourism (and also the development of the tourism industry) did not immediately bring about an increase in the HDI in the group of countries. Only in 2010, when the level of employment in the tourism industry increased, did HDI (measured by access to education, health care and the living standards of people) start showing an upward trend. This was particularly visible in Antigua and Barbuda, and to a lesser extent in the Bahamas and Barbados. The trend weakened in the last year analysed - 2014 (Figure 2).
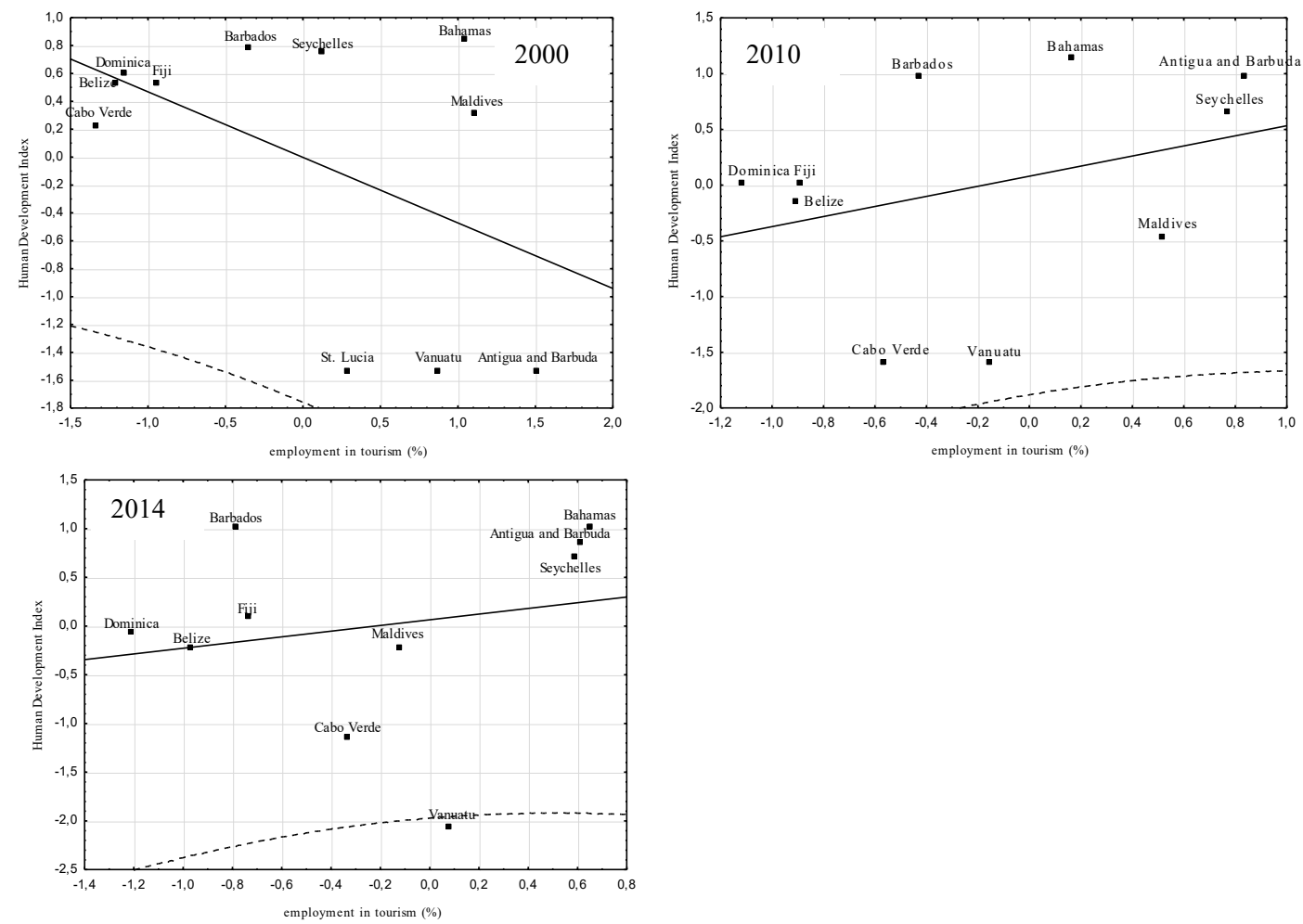

Figure 2. Scatter plots illustrating the relationships between the contribution of tourism to employment and the human development index (HDI) in countries with a high contribution of tourism to creating the GDP in 2000-2015

Source: own elaboration. 


\section{Discussion and conclusions}

Previous studies (e.g. Blancard, Hoarau, 2013; Shareef, Hoti, 2005; Schubert, Brida, Risso 2011) concerning the effects of the development of tourism on the economies of countries which are tourist reception areas point to relationships between their economic growth and the increased growth rate in the demand for international tourism (Schubert, Brida, Risso, 2011, p. 377). This is confirmed for the countries analysed in this paper.

The analysis of relationships between the selected indicators of economic and social development and the contribution of the tourism industry to shaping the national economy follows the statement by Chou (2013) that "the speedy growth of tourism causes an increase in household income and government revenues through multiplier effects, improvement in the balance of payments and growth in the number of tourism-promoted government policies" (p. 226). However, it seems that gradual improvement in the economic situation of the analysed countries (as observed in the period 2000-2010) is not fully reflected in an improved quality of life of their residents. The authors attribute this phenomenon, among other things, to the specific nature of SITE countries (Small Island Tourism Economies). According to Shareef, Hoti (2005, p. 561) "the absence of reliable institutional frameworks in SITEs makes the distribution of income more uneven and results in higher levels of poverty". This can lead to a decrease in the amount of funds allocated to the development of social facilities (e.g. education, health care, culture) and technical infrastructure (contributing to improvement in the living conditions of the people).

(translated by mgr Magdalena Dolny)

\section{References}

Besana, A., Bagnasco, A.M. (2014). Rethinking Tourism in Macroeconomics. Procedia Economics and Finance, 14, 58-67.

Beslerova, S., Dzurickova, J. (2014). Quality of life measurements in EU countries. Procedia Economics and Finance, $12,37-47$.

Antonakakis, N., Dragouni, M., Filis, G. (2015). How strong is the linkage between tourism and economic growth in Europe? Economic Modelling, 44, 142-155.

Dwyer, L., Forsyth, P., Spurr, R. (2004). Evaluating tourism economic effects: new and old approaches. Tourism Management, 25, 307-317.

Trzebiatowski, J. (2011). Jakość życia w perspektywie nauk społecznych i medycznych - systematyzacja ujęć definicyjnych. Hygeia Public Health, 46 (1), 25-31.

Haron, H., Osman, B.M., Maidinsah, H., Maksari, M., Sari, M., MohdZaki, N.Q.M. (2015). Determinants of Quality of Life (QoL) and Quality of University Life (QuL) in Malaysian Public University Students. AIP Conference Proceedings, 1643 (1), 505-551.

Jasiński, M. (2008). Kolonizacja turystyczna, a zaangażowanie lokalnych społeczności w rozwój turystyki. International Journal of Management and Economics, 23, 195-218.

Jędrusik, M. (2003). Trzy modele kolonizacji turystycznej na przykładzie archipelagów mórz ciepłych (Three models of tourist colonisation. Case among the archipelagos of warm seas). Przeglad Geograficzny, 75 (1), 81-98.

UN-OHRLLS (2011). Small Islands Developing States, United Nations, New York, http://unohrlls.org/custom-content/ uploads/2013/08/SIDS-Small-Islands-Bigger-Stakes.pdf.

McElroy, J.L. (2003). Tourism Development in Small Islands Across the World. Geografiska Annaler, 85 B (4), $231-242$. 
Wspólne sprawozdanie dla Parlamentu Europejskiego i Rady Makau: sprawozdanie roczne za 2010 r. Bruksela dnia 14.04.2011 KOM (2011) 205 wersja ostateczna.

Makau str 4, http://ec.europa.eu/transparency/regdoc/rep/1/2011/PL/1-2011-205-PL-F1-1.Pdf.

Shareef, R., Hoti, S. (2005). Small Island tourism economies and country risk rating. Mathematics and Computers in Simulation, 68, 557-570.

Blancard, S., Hoarau, J.F. (2013). A new sustainable development for small island developing states: A reappraisal from data envelopment analysis. Economic Modelling, 30, 623-635.

Schubert, S., Brida, J.G., Risso, W.A. (2011). The impact of international tourism demand on economic growth of small economies dependent on tourism. Tourism Management, 32, 377-385.

\section{JAKOŚĆ ŻYCIA LUDNOŚCI W OBSZARACH RECEPCJI TURYSTYCZNEJ W ŚWIETLE WYBRANYCH WSKAŹNIKÓW}

SŁOWA KLUCZOWE

STRESZCZENIE obszary recepcji turystycznej, wskaźniki makroekonomiczne, turystyka, jakość życia

Turystyka jako gałąź gospodarki w wielu krajach stanowi istotny element przyczyniający się do rozwoju ekonomicznego. Jednocześnie pośrednio może wpływać na warunki i poziom życia ludności. Niniejszy artykuł jest próbą znalezienia zależności pomiędzy sytuacją gospodarczą krajów będących obszarami recepcji turystycznej, a sytuacją ekonomiczną i jakością życia ich mieszkańców. Analizą objęto grupę państw o największym udziale turystyki w tworzeniu GDP. W tym celu autorki analizują wybrane wskaźniki makroekonomiczne i wskaźniki rozwoju społecznego w ujęciu dynamicznym. W celu uzyskania obiektywnych wyników posłużono się wybranymi metodami analizy statystycznej. Otrzymane wyniki skonfrontowano z rezultatami badań międzynarodowych. 